\title{
The features of xylem tracheary elements in some herbaceous members of the family Convolvulaceae Horan.
}

\author{
Ye. V. Goremykina ${ }^{1,2 *}$, A. D. Azaryan ${ }^{1,3}$, E. L. Akime ${ }^{1,4}$, K. Ye. Leshchina ${ }^{1,5}$ \\ ${ }^{1}$ Volgograd State University, Universitetskiy prosp., 100, Volgograd, 400062, Russian Federation \\ 2E-mail: goremykina.eugenia@gmail.com; ORCID iD: https://orcid.org/0000-0003-1193-3239 \\ ${ }^{3}$ ORCID iD: https://orcid.org/0000-0002-6814-433X; ${ }^{4}$ ORCID iD: https://orcid.org/0000-0002-2496-1522 \\ ${ }^{5}$ ORCID iD: https://orcid.org/0000-0001-8184-7710 \\ *Corresponding author
}

Keywords: Convolvulaceae, Cuscuta, diameters of tracheary elements, stem anatomy, vines, xylem.

Summary. Numerous narrow xylem tracheary elements (tracheids and vessels) are present in liana stems, along with a few wide vessels that perform the main water-conducting function. This trait, known as "vessel dimorphism", has been identified in studies on water-conducting tissue in autotrophic plants, including a large number of perennial climbing plants and a number of annual vines. Information is lacking on the presence of vessel dimorphism in parasitic plants of the lianescent habit. In this study, we performed a structural analysis of stems in the autotrophic herbaceous vines of Convolvulus arvensis L. and Calystegia sepium (L.) R. Br., as well as in the parasitic vines of Cuscuta monogyna Vahl, Cuscuta planiflora Ten., Cuscuta approximata Bab., and Cuscuta campestris Yunck., of the family of Convolvulaceae Horan. The xylem of $C$. arvensis and C. sepium contains a few wide conductive elements and many narrow ones. This feature is typical of autotrophic climbing plants. Only narrow tracheary elements are present in the xylem of the parasitic vines of the genus of Cuscuta L. (dodders). The total number of the tracheary elements is an order of magnitude less in the dodders than it is in the autotrophic vines. It is possible that the autotrophic ancestor of dodders lost the characteristic feature of the xylem of climbing plants, known as vessel dimorphism, during its transition to the parasitic lifestyle.

\section{Особенности трахеальных элементов ксилемы у некоторых представителей семейства Convolvulaceae Horan.}

\author{
Е. В. Горемыкина, А. Д. Азарян, Э. Л. Акиме, К. Е. Лещина
}

Волгоградский государственный университет, пр. Университетский, 100, г. Волгоград, 400062, Россия

Ключевые слова: анатомия стебля, вьюнковые, диаметры трахеальных элементов, ксилема, лианы, повилики.

Аннотация. В стеблях лиан присутствуют многочисленные узкопросветные трахеальные элементы ксилемы (трахеиды и сосуды) наряду с немногими широкопросветными сосудами, выполняющими основную проводящую функцию. Эта особенность, известная как «диморфизм сосудов», выявлена при изучении водопроводящей ткани у большого количества многолетних лиан, а также у ряда однолетних автотрофных вьющихся растений. Существует дефицит сведений о наличии диморфизма сосудов у паразитических растений с лианоидной формой роста. В данном исследовании проведен структурный анализ стеблей у автотрофных травянистых лиан Convolvulus arvensis L. и Calystegia sepium (L.) R. Br., а также у паразитических лиан Cuscuta monogyna Vahl, Cuscuta planiflora Ten., Cuscuta approximata Bab. и Cuscuta campestris Yunck., принадлежащих к семейству вьюнковых (Convolvulaceae Horan.). В ксилеме C. arvensis и C. sepium присутствуют немного- 
численные широкие проводящие элементы наряду с многочисленными узкими, что характерно для автотрофных растений с лианоидной формой роста. В ксилеме исследованных паразитических лиан из рода повилика (Cuscuta L.) присутствуют только узкие трахеальные элементы, при этом общее количество трахеальных элементов у повилик на порядок меньше, чем у автотрофных лиан. Не исключено, что характерная особенность ксилемы вьющихся растений, известная как диморфизм сосудов, могла быть утрачена автотрофным предком повилик при переходе к паразитическому образу жизни.

\section{Introduction}

Most representatives of the family of Convolvulaceae Horan. are climbing plants: self-supporting plants predominate in only two of the 12 tribes (Stefanović et al., 2003). The lianescent members of Convolvulaceae can be either autotrophic or heterotrophic, with the latter belonging to the genus of Cuscuta L. (dodders). Dodders are rightly described as the best-known and most widespread parasitic plants, and they have a huge range of hosts. These parasites make their hosts susceptible to secondary infections, as well as inhibit their growth and reproductive function (Sharma et al., 2014; Kaiser et al., 2015). Dodders can also carry viruses from infected plants to healthy ones (Hull, 2014).

The genus of Cuscuta includes about 200 species (Nickrent, 2020). Of these, only 15-20 species cause significant damage to agricultural crops, whereas numerous species of dodders are worthy of conservation efforts (García et al., 2014). At least 16 representatives of the genus of Cuscuta serve as sources of valuable compounds that have a wide range of pharmacological activities (Noureen et al., 2019).

Dodders are not only of practical interest but also of fundamental interest as a specialized group of parasitic plants. In studies on the anatomy of dodders, much attention is paid to the structure of haustoria and their contact with host tissues (Zhuk, 2001; Yoshida et al., 2016; Sun et al., 2018; Shimizu et al., 2019). Another field of research is the study of the stem anatomy of dodders, which makes it possible to assess the functional and diagnostic significance of their structural features (Solereder, 1908; Clayson et al., 2014; Severova, 2019).

In spite of researchers' keen interest in the stem microstructure of dodder stems, we are currently not aware of any work dealing with the features of their xylem that may be related to the lianescent habit of these parasitic plants. It is known that the water-conducting tissue of autotrophic vines is characterized by the presence of a few wide tracheary elements, which perform the main conducting function, and numerous narrow ones, which play a subsidiary role in normal xylem functioning and assume the conducting function in the case of the embolism of wide vessels. The widest vessels stand out sharply against the bulk of the narrower tracheary elements. This peculiarity is usually described as "vessel dimorphism" (Carlquist, 1985). Vessel dimorphism has been detected in numerous species of autotrophic vines from various taxa of flowering plants (Carlquist, 1985; Ewers et al., 1990; Angyalossy et al., 2015, Goremykina et al., 2016), including representatives of the family of Convolvulaceae: in the annual vine of Mina lobata (Carlquist et al., 1991), in the perennial herbaceous vine of Argyreia nervosa (Ewers et al., 1990), and in more than 20 species of woody vines (Carlquist et al., 1991; Rajput et al., 2017). However, the data of a quantitative analysis of sample values of the diameters of tracheary elements are presented only for $A$. nervosa in the work of Ewers et al. (1990). This work was the first to present the results of a statistical study of the quantitative parameters of tracheary elements in an extensive group of lianas, including 33 species from 26 genera belonging to 16 families of flowering plants. Statistical analysis of samples of tracheary element diameters revealed a common pattern in xylem of climbing plants from different taxa: the presence of an obvious shift in the ratio between narrow and wide tracheary elements towards narrow ones. This occurred despite the fact that some of the narrowest xylem elements were not discernible on cross-sections and were not taken into account. In the presented histograms of the frequency distribution of the sample values of diameters, a peak exists in the area of small diameters. To the right of the peak are a few far-reaching values that do not form a clearly delimited group; rather, they represent an intermediate series between the small and the largest diameters. This type of frequency distribution of tracheary element diameters was repeatedly revealed later in similar studies in the xylem of other plants with a lianescent habit (Tibbetts et al., 2000; Ganthaler et al., 2019).

Dodders are certainly related to autotrophic vines as evidenced by the monophyly of the family of Convolvulaceae, which molecular phylogenetic studies have confirmed. It has been proven that at least two nonparasitic lineages diverge within the 
family before Cuscuta (Stefanović et al., 2003). However, the exact position of the genus of Cuscuta in the family has not yet been determined despite extensive analysis (Nickrent, 2020). Although no definite opinion exists on the ancestor and the sister group of the dodders, A. V. Zhuk's point of view that dodders originated from autotrophic herbaceous vines of the Convolvulaceae family is justified. Only this can explain the fact that all members of the genus of Cuscuta are vines without exception. This also explains the fact that the penetration of haustoria into host tissues requires a tight twisting of the parasite stem around the host organs (Zhuk, 2001). It should be noted that autotrophic vines are considered structural or mechanical parasites because they compete with their supporting plants for light and soil resources; as a result, they negatively affect their hosts (Ewers et al., 2015; Visser et al., 2019).

The following question arises: do the dodders have the same frequency distribution of the diameters of the tracheary elements that their relatives autotrophic vines from the Convolvulaceae family - have? The answer requires a comparative analysis of the frequency distribution of tracheary element diameters in herbaceous autotrophic vines and parasitic vines of the family of Convolvulaceae. This will broaden our understanding of their waterconducting system and enable us to speculate on the direction in which the xylem of an autotrophic structural parasite may have been transformed into the xylem of a heterotrophic vine.

The aim of this study was to find out whether differences exist in the frequency distribution of tracheary diameter values between heterotrophic and autotrophic herbaceous vines of the Convolvulaceae family.

\section{Materials and Methods}

The experimental objects were Convolvulus arvensis L., Calystegia sepium (L.) R. Br., Cuscuta monogyna Vahl, Cuscuta planiflora Ten., Cuscuta approximata Bab., and Cuscuta campestris Yunck. The material was collected during the flowering period in the summer seasons of 2014-2020 in the Ilovlinsky and Sredneakhtubinsky districts of Volgograd Region. The material was also collected in the city of Volgograd in the vicinity of Volgograd State University. The shoots were fixed in $95 \%$ ethanol. Cross-sections were prepared manually from the middle parts of internodes. The sections were stained using the phloroglucinol reaction (Barykina et al., 2004) and were embedded in glycerol.

Photographs of cross-sections and measurements were generated using a Mikmed-5 microscope, a ToupCam 9.0 digital camera, and ToupViev 3.7 software. On the basis of the photos, schemes of the sections were designed with Photoshop CC software.

For each species, the diameters of the tracheary elements were measured at two developed internodes in at least five plants from the same habitat. In C. arvensis and C. sepium, tracheary element diameters were measured in a randomly selected sector, which included 10 radial rows of xylem elements. The angular size of the sector averaged $58^{\circ}$ in C. arvensis and $41^{\circ}$ in C. sepium. In dodders, the internodes without haustoria were examined, and the diameters of all tracheary elements were measured in the cross-section. Because the conductive elements were not strictly circular, following the Ewers method (Ewers et al., 1990), the minimum and maximum diameters were averaged for each element. Then, the average values were used for further statistical processing using STATISTICA 10. The Shapiro-Wilk test was used to check whether the distribution of the sample values conformed to normal. Because the distributions of the diameters of the tracheary elements in samples of all the species, except for $C$. planiflora, were significantly different from normal, the nonparametric Mann-Whitney and Kruskal-Wallis tests were used for further statistical processing.

\section{Results}

\section{Autotrophic herbaceous vines}

$C$. arvensis and $C$. sepium have similar stem structures at the internodes studied (Fig. 1A-B). Their cross-sections are rounded, with two to five small ribs unevenly distributed around the circumference of the stems. An epidermis covers the cortex, which consists of the subepidermal chlorenchyma, the middle layer of collenchyma cells, and the inner layer of thin-walled cells. At the periphery of the stele is a ring of weakly lignified mechanical elements. Under it, a small-celled soft phloem and a highly lignified xylem are located in continuous layers. The primary xylem is adjoined by five to eight strands of the inner phloem that penetrates into the pith, which is composed of large, thin-walled, non-lignified cells. Some specimens have a small rexigenous cavity in the center of the pith. The cambium unevenly produces new elements around the circumference of the stem. The greatest activity is observed in several areas, thus resulting in one to 
five groups of secondary xylem elements, including the widest vessels. These groups protrude into the outer phloem zone.

Using the number of tracheary elements that fell into the sector for measuring diameters in this study, one can estimate their number in the entire crosssection: in C. arvensis, it is 400 on average, and the number is 718 in C. sepium.

The distribution of sample values of tracheary element diameters in both species is significantly different from the normal distribution according to the Shapiro-Wilk test at $\mathrm{p}<<0.05$. The statistically significant difference between the sampled values of the diameters of $C$. arvensis and $C$. sepium was confirmed by the nonparametric Mann-Whitney test at $\mathrm{p}<<0.05$.

The frequency distributions of diameters in both species have a distinctly positive skew: the smallest values have a peak, followed on the right by a long series of relatively infrequent large values (Fig. 2A-B). This distribution indicates the presence of numerous narrow conductive elements and a few wide ones.
The coefficients of skewness of the diameter distributions are 1.76 in C. arvensis and 2.24 in C. sepium (Table). Positive values of this parameter are known to indicate the positively skewed (or rightskewed) distribution of sample values, whereas zero corresponds to a symmetric distribution of data sets (Fay et al., 2013). The statistical significance of positive skewness in these cases is confirmed by the fact that zero does not fall within the $95 \%$ confidence intervals of both coefficients of skewness (Fig. 3B).

The range of diameter values reaches $75.7 \mu \mathrm{m}$ (from 4.2 to $79.9 \mu \mathrm{m}$ ) in C. arvensis and $113.7 \mu \mathrm{m}$ (from 3.4 to $117.1 \mu \mathrm{m}$ ) in C. sepium (Table; Figs 2A-B, 3A); therefore, for $C$. arvensis, the maximum diameter value is 19 times the minimum value, and for $C$. sepium, it is 34.4 times. Due to such a large range of diameters, the widest vessels stand out sharply against the background of the bulk of narrow tracheary elements on the transverse sections of the stems (Fig. 1A-B). This makes it possible to observe vessel dimorphism as a feature in the xylem of the autotrophic vines.

Table

Statistics of sampled diameters of tracheary elements in the studied species

\begin{tabular}{|c|c|c|c|c|c|c|c|}
\hline Species & 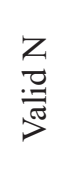 & 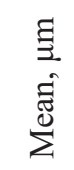 & 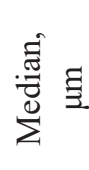 & 志志 & 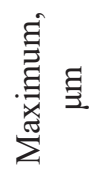 & 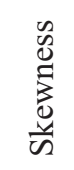 & 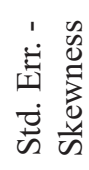 \\
\hline Convolvulus arvensis & 647 & 16.0 & 12.4 & 4.2 & 79.9 & 1.76 & 0.10 \\
\hline Calystegia sepium & 819 & 21.5 & 17.9 & 3.4 & 117.1 & 2.24 & 0.09 \\
\hline Cuscuta monogyna & 406 & 12.7 & 12.2 & 4.7 & 26.1 & 0.44 & 0.12 \\
\hline Cuscuta campestris & 311 & 10.9 & 10.8 & 4.9 & 24.2 & 0.63 & 0.14 \\
\hline Cuscuta approximata & 230 & 5.7 & 5.6 & 2.5 & 11.8 & 0.63 & 0.16 \\
\hline Cuscuta planiflora & 226 & 6.4 & 6.4 & 1.8 & 12.0 & 0.27 & 0.16 \\
\hline
\end{tabular}

\section{Parasitic vines}

The stem structure of the examined dodders has a similar pattern in the middle part of the internodes without haustoria (Fig. 1C-F). Their cross-sections are rounded or finely ribbed. The parenchymatous cortex is located under the epidermis. Subepidermal cortical cells often feature the collenchymatous thickening of their walls. The cells of the median layer of the cortex may be compressed radially. Their deformation is usually accompanied by the formation of fold-like ribs on the periphery of the stem. The boundary between the cortex and the stele is indistinct. The conducting system is composed of collateral bundles. Incomplete bundles consisting of only phloem may also be present.
The stem of C. monogyna is comparable in thickness to the stems of the autotrophic lianas (Fig. 1C). The stele of the dodder usually features 9-10 conductive bundles. Each bundle is accompanied by a group of weakly lignified cells that are adjacent to the outer part of the soft cells of the phloem. The xylem and the inter-bundle parenchyma are highly lignified. Lignified cells are sometimes found in the pith. An average of 41 tracheary elements are located in a cross-section of the stem of C. monogyna.

The stems of the other dodders are thinner; the lignification of the inter-bundle parenchyma is absent in them (Fig. 1D-F). 


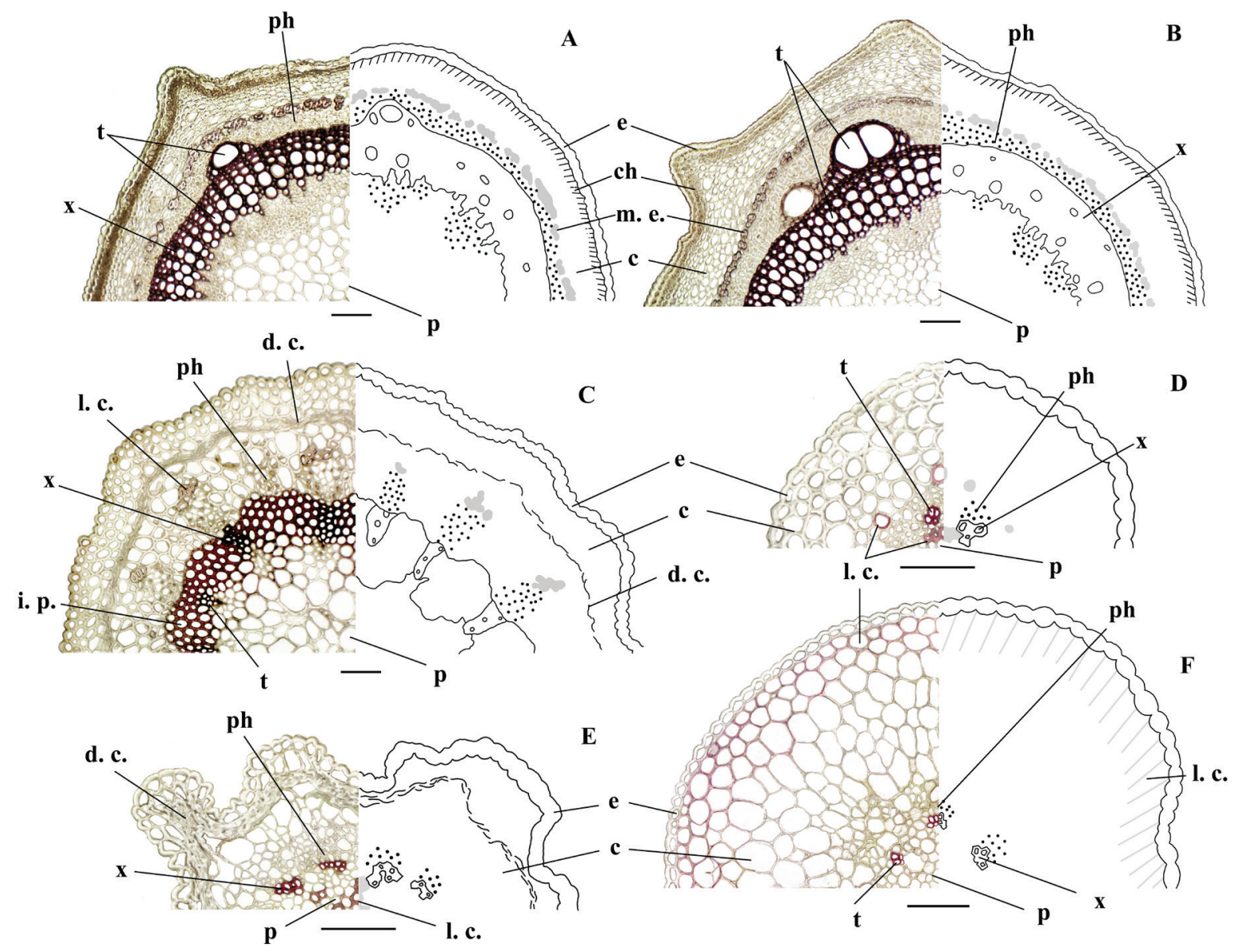

Fig. 1. Cross-sections of the stems of Convolvulus arvensis (A), Calystegia sepium (B), Cuscuta monogyna (C), Cuscuta planiflora (D), Cuscuta approximata (E), Cuscuta campestris (F); d. c. - deformed cells of the cortex; c - cortex; ch - chlorenchyma; e-epidermis; i. p. - inter-bundle parenchyma; 1. c. - lignified cells; m. e. - mechanical elements; $\mathrm{p}$ - pith; ph - phloem; $\mathrm{t}$ - tracheary elements; $\mathrm{x}$ - xylem. Scale bar is $100 \mu \mathrm{m}$.
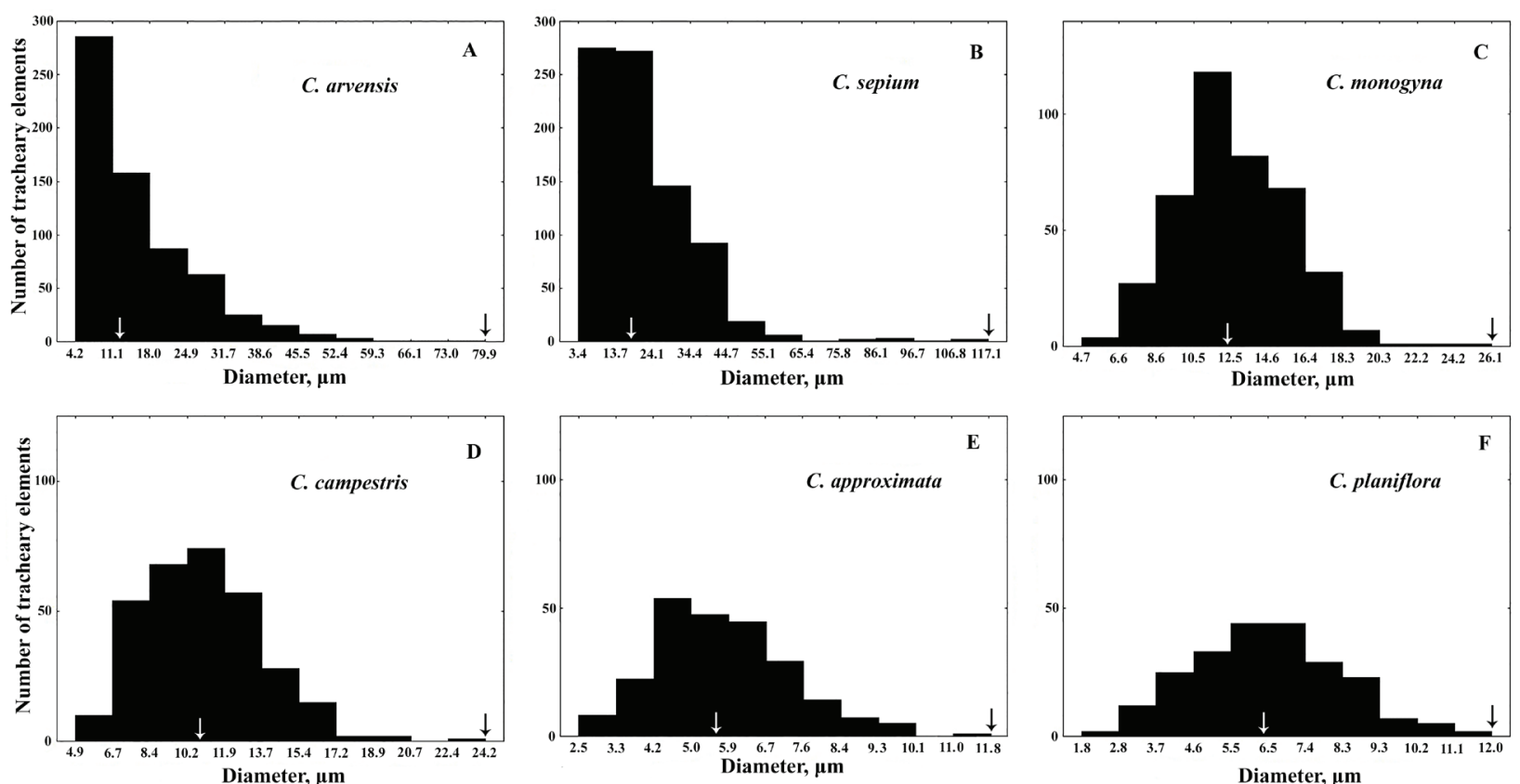

Fig. 2. Frequency distribution of tracheary element diameters in Convolvulus arvensis (A), Calystegia sepium (B), Cuscuta monogyna (C), Cuscuta campestris (D), Cuscuta approximata (E), Cuscuta planiflora (F). The white arrows point out the medians, and the black arrows point out the maximum diameters. 
In some specimens of $C$. campestris, the subepidermal layer of the cortex is lignified, which is not found in the other parasitic vines (Fig. 1F). In this dodder, individual lignified cells may occasionally be found in the pith and on the periphery of the stele, which includes six to nine vascular bundles. Weak cambial activity is noted in single bundles of this dodder only. An average of 31 tracheary elements are located in a cross-section of the stem of C. campestris.

Both C. planiflora and C. approximata have four to seven vascular bundles in the stele (Fig. 1D-E). On average, there are 23 tracheary elements on the cross-sections of the stems in the xylem of $C$. approximata, and 19 in the xylem of $C$. planiflora. Specimens of C. planiflora are more sclerified: lignified cells are usually found on the periphery of stele and in the pith, whereas in C. approximata such cells are noted in single specimens.

The distribution of the sample values of tracheary element diameters in all of the dodders, except for $C$. planiflora, is significantly different from the normal distribution according to the Shapiro-Wilk test at $\mathrm{p}<<0.05$. The sample values of $C$. planiflora have a normal distribution confirmed by the same test at $p=0.33>0.05$. Statistically significant differences between the sample values of tracheary element diameters were confirmed using the Kruskal-Wallis nonparametric test at $\mathrm{p}<<0.05$, and a posteriori pairwise comparisons were made using the Mann-Whitney test at $\mathrm{p}<<0.0085$ (with a Bonferroni correction) for each pair.

The distributions of sampled diameters have a slightly positive skewness in all of the dodders. It is not as pronounced as it is in the autotrophic vines (Fig. 2). The peaks of the histograms occur at inter- vals that include the medians of the samples of diameters in C. monogyna, C. campestris and C. planiflora (Fig. 2C-D, F). In C. approximata, the peak is in the interval, the upper boundary of which is shifted from the median towards lower values by $0.6 \mu \mathrm{m}$ (Fig. 2E). All of the dodders have few values in the smallest diameter class as well as in the largest diameter class (Fig. 2C-F).

The presence of the positive skewness is confirmed by positive coefficients of skewness: 0.44 in C. monogyna, 0.63 both in $C$. campestris and in C. approximata, and 0.27 in C. planiflora (Table). The asymmetry of the sample value distribution in C. planiflora should obviously be deemed insignificant, as unlike the other dodders, in this species, the $95 \%$ confidence interval of the coefficient of skewness includes zero (Fig. 3B).

The range of diameter values is $21.4 \mu \mathrm{m}$ in C. monogyna (from $4.7 \mu \mathrm{m}$ to $26.1 \mu \mathrm{m}$ ), $19.3 \mu \mathrm{m}$ in C. campestris (from 4.9 to 24.2 ), $9.3 \mu \mathrm{m}$ in C. approximata (from $2.5 \mu \mathrm{m}$ to $11.8 \mu \mathrm{m}$ ) and $10.2 \mu \mathrm{m}$ in C. planiflora (from $1.8 \mu \mathrm{m}$ to $12.0 \mu \mathrm{m}$ ) (Table; Figs $2 \mathrm{C}-\mathrm{F}, 3 \mathrm{~A})$. The maximum value is 5.6 times greater than the minimum value in C. monogyna, 4.9 times greater in C. campestris, 4.7 times greater in C. approximata and 6.7 times greater in C. planiflora. Such a small difference between the diameters of the widest and narrowest tracheary elements compared to that present in the autotrophic vines, as well as the relative paucity of the narrowest tracheary elements, do not allow one to see sharp differences between the widest and the rest of the narrower tracheary elements on the transverse sections of the dodder stems. As a result, we do not observe vessel dimorphism in the xylem of the parasitic vines (Fig. 1C-F).
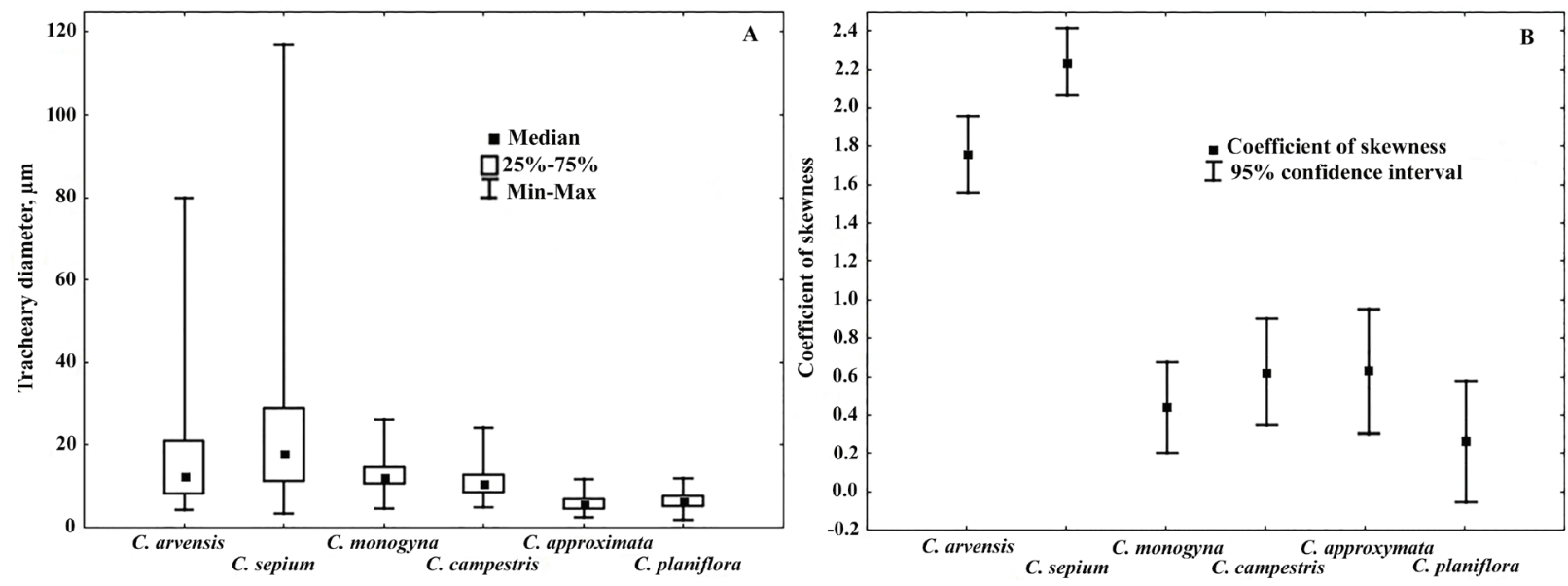

Fig. 3. Statistics of sampled diameters of tracheary elements in the studied species: A - the range of the diameter values; $\mathrm{B}-$ the coefficients of skewness. 


\section{Discussion}

The study revealed a number of significant differences between the quantitative characteristics of the tracheary elements of the xylem in the autotrophic and heterotrophic vines. These differences primarily concern the total number of tracheary elements, as well as the range of values and frequency distribution of diameters in the samples of tracheary elements.

The number of tracheary elements is an order of magnitude less in all of the dodders than it is in the autotrophic vines. The range of diameter values is also smaller in dodders - on average, it is reduced by 6.3 times in comparison with the autotrophic vines, while minimum values of both autotrophic and parasitic vines are practically at the same level. However, the level of maximum diameter is much lower in parasites - on average, 5.3 times than the maximum diameters of autotrophs (Table; Fig. 3A). This indicates the presence of only relatively narrow tracheary elements in the samples of the dodders as compared to the samples of tracheary elements in the autotrophic vines. It is remarkable that the widest tracheal elements of dodders are lost in the general mass of other narrower elements of their xylem because they do not stand out against their background, which does not allow observation of the vessel dimorphism in the parasitic vines that is so evident in the autotrophic vines (Fig. 1).

The pattern of the frequency distribution of tracheary element diameters also differs significantly between the autotrophic and heterotrophic objects of investigation. In $C$. arvensis and $C$. sepium, the distributions are sharply asymmetrical with the positive skew due to the presence of a number of values deviating towards larger diameters. The positive skew in the diameter distributions is less pronounced in C. monogyna, C. campestris and C. approximata and virtually absent in C. planiflora, in which the sample of diameters has a statistically confirmed normal distribution. In all of the dodders, the coefficients of skewness are significantly less than they are in the autotrophic vines. This is confirmed by the absence of the intersection between their $95 \%$ confidence intervals (Fay et al., 2013) (Fig. 3B).

The asymmetry of the diameter distribution in C. monogyna, C. campestris, and C. approximata stems from the presence of a few widest diameters in the samples. The removal of these diameters makes the samples almost symmetric: their coefficients of skewness sharply decrease, and zero falls within the coefficients' $95 \%$ confidence intervals. C. monogy$n a$ had only $0.005 \%$ of such diameters in the sample (two out of 406), C. campestris only $0.01 \%$ (three out of 311 ), and C. approximata only $0.02 \%$ (five out of 230). In comparison, $43 \%$ (278 out of 647) and $40 \%$ (328 out of 819 ) of the larger diameters in C. arvensis and C. sepium, respectively, would have to be removed from the samples to reduce the coefficients of skewness to levels where zero would fall within their $95 \%$ confidence intervals.

These tracheary elements of dodders that cause the slight skewness towards larger values should not be ignored as incidental outliers, because any outlier of sample values requires careful analysis (Fay et al., 2013). We have no reason to believe that the appearance of such values in the samples is due to measurement errors. The presence of such outliers in dodders may be a feature inherited from their autotrophic lianescent ancestor, which had the pronounced positive skewness of the distribution of the tracheary element diameters.

The loss of wide xylem elements, together with a significant part of narrow ones, is to be expected during the transition to parasitism in the ancestor of dodders. Wide vessels with high conductivity are necessary for autotrophic vines to efficiently transport water over large distances along thin yet extremely long stems from the roots to a huge mass of foliage (Ewers et al., 1990). Dodders have no need for an intensive water supply due to the lack of foliage leaves and the reduced distances over which vital resources must be moved. These parasites attach to the host in many sites, each of which serves as a source of organics and water. Transport is restricted to the area between the attachment points. At distances measured in centimetres, wide vessels and a significant part of narrow xylem elements have become redundant, whereas a small number of remaining narrow tracheary elements turned out to be quite sufficient for local xylem transport.

In conclusion, the study revealed significant differences in the frequency distribution of the tracheary element diameters in heterotrophic and autotrophic herbaceous vines from the Convolvulaceae family. The autotrophic $C$. arvensis and $C$. sepium have a typical distribution pattern of climbing plants: numerous narrow and a few broad conductive elements are present in their xylem. The distribution of the sampled values of their diameters is asymmetric, with a pronounced positive (right) skewness towards the wide vessels being evident.

The xylem of C. monogyna, C. campestris, C. approximata, and C. planiflora contains only nar- 
row tracheary elements. The total number of the elements is an order of magnitude less than that of the autotrophic vines. The distribution of the sampled values of the diameters of these xylem elements is close to symmetric with a slightly positive skewness.

It can be assumed that the transition to parasitism in the ancestor of dodders was accompanied by the disappearance of wide vessels against the background of a decrease in the total number of tracheary elements. As a result, the autotrophic mechani- cal parasite might have lost the trait known as vessel dimorphism during its transformation into the true heterotrophic parasite, which retained the lianescent habit.

\section{Acknowledgments}

The authors are grateful to Dr. V. A. Sagalaev (Biology Department of Volgograd State University) for his help with identifying the research objects. We also thank the anonymous reviewer for valuable comments to the manuscript.

\section{REFERENCES / ЛИTЕРАTУРA}

Angyalossy V., Pace M. R., Lima A. C. 2015. Liana anatomy: a broad perspective on structural evolution of the vascular system. In: Ecology of Lianas. Chichester: Wiley-Blackwell. Pp. 253-287. DOI: 10.1002/9781118392409. ch19

Barykina R. P., Veselova T. D., Devyatov A. G., Dzhalilova Kh. Kh., Ilina G. M., Chubatova N. V. 2004. Spravochnik po botanicheskoy mikrotekhnike. Osnovy i metody [Handbook of botanical microtechnology. Basics and methods]. Moscow: MSU Publ. 312 pp. [In Russian]. (Барыкина Р. П., Веселова Т. Д., Девятов А. Г., Джсалилова X. Х., Ильина Г. М., Чубатова Н. В. Справочник по ботанической микротехнике. Основы и методы. М.: МГУ, 2004. 312 c.).

Carlquist S. 1985. Observations on functional wood histology of vines and lianas: vessel dimorphism, tracheids, vasicentric tracheids, narrow vessels, and parenchyma. Aliso (11)2: 139-157. DOI: 10.5642/aliso.19851102.03

Carlquist S., Hanson M. A. 1991. Wood and stem anatomy of Convolvulaceae: a survey. Aliso (13)1: 51-94. DOI: 10.5642/aliso. 19911301.03

Clayson C., García-Ruiz I., Costea M. 2014. Diversity, evolution, and function of stomata bearing structures in Cuscuta (dodders, Convolvulaceae): From extrafloral nectar secretion to transpiration in arid conditions. Perspect. Plant Ecol. 16(6): 310-321. DOI: 10.1016/j.ppees.2014.08.004

Ewers F. W., Fisher J. B., Chiu S.-T. 1990. A survey of vessel dimensions in stems of tropical lianas and other growth forms. Oecologia (84)4: 544-552. DOI: 10.1007/BF00328172

Ewers F. W., Rosell J. A., Olson M. E. 2015. Lianas as Structural Parasites. In: Functional and Ecological Xylem Anatomy. Springer: Cham. Pp. 163-188. DOI: 10.1007/978-3-319-15783-2_6

Fay D. S., Gerow K. 2013. A biologist's guide to statistical thinking and analysis. In: WormBook: The Online Review of C. elegans Biology. URL: http://www.wormbook.org/chapters/www_statisticalanalysis/statisticalanalysis. html (Accessed 24 February 2021).

Ganthaler A., Marx K., Beikircher B., Mayr S. 2019. Are hydraulic patterns of lianas different from trees? New insights from Hedera helix. J. Exp. Bot. (70)10: 2811-2822. DOI: 10.1093/jxb/erz071

García M. A., Costea M., Kuzmina M., Stefanović S. 2014. Phylogeny, character evolution, and biogeography of Cuscuta (dodders; Convolvulaceae) inferred from coding plastid and nuclear sequences. Am. J. Bot. 101(4): 670-690. DOI: $10.3732 / a j b .1300449$

Goremykina E. V., Dinekina E. A. 2016. Traits of stem anatomy of some herbaceous members of the family Polygonaceae Juss. Moscow Univ. Biol. Sci. Bull. 71: 121-125. DOI: 10.3103/S0096392516030056

Hull R. 2014. Plant to Plant Movement. In: Plant Virology. San Diego: Academic Press. Pp. 669-751. DOI: 10.1016/b978-0-12-384871-0.00012-1

Kaiser B., Vogg G., Fürst U. B., Albert M. 2015. Parasitic plants of the genus Cuscuta and their interaction with susceptible and resistant host plants. Front. Plant Sci. 6: 45. URL: https://www.frontiersin.org/article/10.3389/ fpls.2015.00045 (Accessed 24 February 2021).

Nickrent D. L. 2020. Parasitic angiosperms: how often and how many? Taxon 69(1): 5-27. DOI: 10.1002/tax.12195

Noureen S., Noreen S., Ghumman S. A., Batool F., Bukhari S. N. A. 2019. The genus Cuscuta (Convolvulaceae): An updated review on indigenous uses, phytochemistry, and pharmacology. Iran. J. Basic Med. Sci. 22(11): 1225-1252. DOI: 10.22038/ijbms.2019.35296.8407

Rajput K. S., Lekhak M. M., Kapadane K. K., Yadav S. R. 2017. Formation of tri-lobed stem and successive cambia in the stems of Argyreia hookeri C. B. Clarke (Convolvulaceae). Flora 233: 140-149. DOI: 10.1016/j.flora.2017.06.005

Severova Ye. E. 2019. Stem anatomy of middle Russian dodders (Cuscuta L.). In: Plant anatomy: traditions and perspectives. Proceedings of the International Symposium, dedicated to the 90th anniversary of Prof. Ludmila 
Ivanovna Lotova. Part 2. Moscow: MAKS Press. Pp. 253-264. [In Russian] (Северова Е. Э. Анатомия стеблей среднерусских повилик (Cuscuta L.) // Анатомия растений: традиции и перспективы: материалы международного симпозиума, посвященного 90-летию профессора Людмилы Ивановны Лотовой. Ч. 2. (г. Москва, 16-22 сентября 2019 г.). М.: МАКС пресс, 2019. С. 253-264).

Sharma Y. P., Kapoor V. 2014. Parasitic angiosperms and biology of Cuscuta species - an overview. In: Review of Plant Pathology. Vol. 6. Jodhpur: Scientific Publishers. Pp. 577-608.

Shimizu K., Aoki K. 2019. Development of parasitic organs of a stem holoparasitic plant in genus Cuscuta. Front. Plant Sci. 10: 1435. URL: https://www.frontiersin.org/articles/10.3389/fpls.2019.01435/full (Accessed 24 February 2021).

Solereder H. 1908. Systematic anatomy of the dicotyledons. A handbook for laboratories of pure and applied botany. Vol. 2. Oxford: Clarendon Press. P. 1182.

Stefanović S., Austin. D., Olmstead R. G. 2003. Classification of Convolvulaceae: a phylogenetic approach. Syst. Bot. 28(4): 791-806. DOI: 10.1043/02-45.1

Sun G., Xи Y., Liu H., Sun T., Zhang J, Hettenhausen C., Shen G., Qi J., Qin Y., Li J., Wang L., Chang W., Guo Z., Baldwin I.T., Wu J. 2018. Large-scale gene losses underlie the genome evolution of parasitic plant Cuscuta australis. Nat. Commun. 9: 2683. URL: https://www.nature.com/articles/s41467-018-04721-8\#citeas (Accessed 24 February 2021).

Tibbetts T., Ewers F. 2000. Root pressure and specific conductivity in temperate lianas: exotic Celastrus orbiculatus (Celastraceae) vs. native Vitis riparia (Vitaceae). Am. J. Bot. 87(9): 1272-1278. DOI: 10.2307/2656720

Visser M. D., Muller-Landau H. C., Schnitzer S. A., de Kroon H., Jongejans E., Wright S. J. 2018. A hostparasite model explains variation in liana infestation among co-occurring tree species. J. Ecol. 106(6): 2435-2445. DOI: 10.1111/1365-2745.12997

Yoshida S., Cui S., Ichihashi Y., Shirasu K. 2016. The haustorium, a specialized invasive organ in parasitic plants. Annu. Rev. Plant Biol. 67: 643-667. DOI: 10.1146/annurev-arplant-043015-111702

Zhuk A. V. 2001. The origin of parasitism in flowering plants. Vestnik Sankt-Peterburgskogo universiteta. Seriya 3. Biologiya [Bulletin of St. Petersburg State University. Series 3. Biology] 1, 3: 24-37. [In Russian] (Жук A. В. Происхождение паразитизма у цветковых растений // Вестник СПбГУ. Серия 3. Биология, 2001. Вып. 1, № 3. С. 24-37). 